\title{
EKSPLORASI JAMUR ASAL TANDAN KOSONG KELAPA SAWIT YANG BERPOTENSI SEBAGAI AGEN PENDEGRADASI SELULOSA
}

\section{EXPLORATION OF CELLULOLITYC FUNGI FROM OIL PALM EMPTY FRUIT BUNCHES POTENTIAL AS CELLULOSE DEGRADING AGENT}

\author{
Agustinur* \& Yusrizal \\ Fakultas Pertanian, Universitas Teuku Umar, Meulaboh , Indonesia \\ *Email: agustinur.hamka@gmail.com \\ * Corresponding Author, Diterima: 3 Juli 2021, Direvisi: 22 Ags 2021, Disetujui: 12 Sep. 2021
}

\begin{abstract}
One of the problems in agriculture is the abundance of waste that cannot be utilized optimally, such as oil palm empty fruit bunches (OPEFB). The largest component contained in OPEFB is cellulose. These components tend to be difficult to degrade in nature. Several biological agents are known to degrade cellulose because they have cellulolytic potency. This study aims to isolate fungi from OPEFB waste which have the potential to degrade cellulose, that can be utilized to optimally degrade the waste. The research begin by collecting sample of decomposed EFB which is located in the oil palm plantation area of PT Agro Sinergi Nusantara, Aceh Jaya Regency, Aceh. Then the isolation of fungi conducted from the sample. The results of the isolation have been obtained 18 isolates of fungi. Furthermore, the isolates were purified and tested for their cellulolytic potential by growing on CMC media. Based on the results of the cellulolytic potential test, 17 isolates had potential with indicators of the formation of a clear zone around the colony. Among the 17 isolates, there were 3 fungal isolates with high cellulolytic potential category, namely isolates JM714, JM402 and JM609, with cellulolytic indexes of 6.5, 3.47 and 2.1, respectively. After identification, isolate JM714 was suspected to be a member of the genus Aspergillus, while isolates JM402 and JM609 were members of the genus Trichoderma.
\end{abstract}

Keywords: Cellulolytic, cellulose, degrading, fungi, Oil Palm Empty Fruit Bunches (OPEFB).

\begin{abstract}
ABSTRAK
Salah satu permasalahan yang dihadapi dalam bidang pertanian adalah melimpahnya limbah yang belum dapat dimanfaatkan secara optimal seperti tandan kosong kelapa sawit (TKKS). Komponen terbesar yang terkandung di dalam TKKS adalah selulosa. Komponen ini cenderung sulit terdegradasi di alam. Beberapa agens hayati dari kelompok jamur diketahui dapat mendegradasi selulosa karena memiliki kemampuan selulolitik. Penelitian ini bertujuan untuk mengisolasi jamur asal limbah TKKS yang memiliki potensi untuk mendegradasi selulosa, sehingga nantinya dapat dimanfaatkan dalam mendegradasi limbah TKKS secara optimal. Tahapan penelitian dimulai dari pengambilan sampel TKKS terdekomposisi yang berada di area perkebunan kelapa sawit PT Agro Sinergi Nusantara Kabupaten Aceh Jaya, Aceh. Kemudian dari sampel tersebut dilakukan tahapan isolasi jamur. Hasil isolasi tersebut telah diperoleh sebanyak 18 isolat jamur. Selanjutnya isolat-isolat tersebut dipurifikasi dan diuji potensi selulolitiknya dengan cara ditumbuhkan pada media CMC. Berdasarkan hasil uji potensi selulolitik
\end{abstract}


diperoleh sebanyak 17 isolat yang memiliki potensi dengan indikator terbentuknya zona bening di sekeliling koloni. Di antara 17 isolat tersebut terdapat 3 isolat jamur dengan kategori potensi selulolitik tinggi yaitu isolat JM714, JM402 dan JM609, dengan indeks selulolitik berturut-turut sebesar 6,5, 3,47 dan 2,1. Setelah dilakukan identifikasi isolat JM714 diduga merupakan anggota genus Aspergillus, sementara isolat JM402 dan JM609 adalah anggota genus Trichoderma.

Kata kunci : Degradasi, jamur, selulolitik, selulosa, Tandan Kosong Kelapa Sawit (TKKS).

\section{PENDAHULUAN}

Salah satu permasalahan yang dihadapi dalam bidang pertanian dan perkebunan adalah melimpahnya limbah yang belum dapat termanfaatkan dengan baik. Diantara bahan yang paling banyak terkandung dalam limbah tersebut adalah komponen lignoselulosa. Komponen ini terdiri dari tiga polimer yaitu selulosa, hemiselulosa dan lignin. Dari ketiga komponen tersebut, selulosa memiliki persentase paling tinggi di dalam limbah, yaitu berkisar 35-50\% (Saha, 2004). Komponen ini cenderung sulit terdegradasi di alam karena susunannya yang heterogen. Selulosa merupakan polimer linier dari D-glukosa yang terikat pada ikatan 1,4 glikosidik dan sangat erat berasosiasi dengan hemiselulosa dan lignin (Anindyawati, 2010).

Salah satu permasalahan limbah perkebunan yang hingga saat ini belum selesai adalah Tandan Kosong Kelapa Sawit. Kelimpahan limbah ini terus meningkat seiring dengan perluasan areal perkebunan. Setiap produksi 1 ton tandan buah segar (TBS) akan dihasilkan tandan kosong kelapa sawit (TKKS) sebanyak 25\% (Santi, et al., 2018). Pemanfaatan TKKS tersebut sampai saat ini belum dilakukan dengan optimal. Petani kelapa sawit umumnya hanya membiarkan limbah tersebut menumpuk atau membakarnya. Pembakaran dan penumpukan TKKS menyebabkan masalah selanjutnya yaitu timbulnya bau tidak sedap dan polusi serta menyebabkan penurunan kualitas tanah (Rahman et al., 2016).

Tandan Kosong Kelapa Sawit (TKKS) memiliki kandungan selulosa $45.95 \%$, hemiselulosa 16.49\%, dan lignin 22.84\% (Murdani, 2017). Secara alami komponen ini memerlukan waktu yang cukup lama untuk terdegradasi, yaitu berkisar 6 bulan (Jumirah et al., 2018). Salah satu faktor penting yang menentukan keberhasilan proses dekomposisi TKKS adalah mikroorganisme seperti jamur yang berperan sebagai bioaktivator dalam mendegradasi komponen yang terkandung di dalam TKKS (Aini et al., 2021). Mikroorganisme tersebut diketahui memiliki kemampuan selulolitik sehingga mampu menghidrolisis selulosa menjadi produk yang lebih sederhana. Proses biokonversi limbah tersebut sangat perlu dilakukan guna mendapatkan nilai tambah dari bahan limbah menjadi produk lain yang lebih berguna seperti pupuk, bioetanol, pakan ternak dan sebagainya. Beberapa jamur yang diketahui memiliki kemampuan dalam proses biokonversi tersebut antara lain Trichoderma, Aspergillus,Penicillium, Gliocladium Paecilomyces, Neurospora, Fusarium, Gonatobotryum dan Syncephalastrum (Affandi et al., 2001; Kadarmoidheen et al., 2012). Mengingat pentingnya jamur pendegradasi selulosa, maka penelitian ini dilakukan untuk mendapatkan isolat jamur dari limbah tandan kosong 
kelapa sawit yang memiliki kemampuan dalam mendegradasi selulosa.

\section{BAHAN DAN METODE}

Sampel yang digunakan dalam penelitian ini adalah tandan kosong kelapa sawit (TKKS) yang sedang mengalami dekomposisi. Sampel diambil di perkebunan kelapa sawit milik PT Agro Sinergi Nusantara, Aceh Jaya. Media isolasi dan pertumbuhan jamur yang digunakan adalah Potato Dextrose Agar (PDA) merk Oxoid, sementara untuk pengujian potensi selulolitik digunakan media Carboxymethyl Cellulose (CMC) dengan komposisi per liter yaitu Agar $10 \mathrm{~g}$; $\mathrm{NaNO}_{3}, 2 \mathrm{~g} ; \mathrm{K}_{2} \mathrm{HPO}_{4}, 0,5 \mathrm{~g} ; \mathrm{MgSO}_{4} .7 \mathrm{H}_{2} \mathrm{O}, 0,02 \mathrm{~g}$; $\mathrm{MnSO}_{4} \cdot 7 \mathrm{H}_{2} \mathrm{O}, 0,02 \mathrm{~g} ; \mathrm{FeSO}_{4} \cdot 7 \mathrm{H}_{2} \mathrm{O}, 0,02 \mathrm{~g}$; $\mathrm{CaCl}_{2} \cdot 2 \mathrm{H}_{2} \mathrm{O}, 5 \mathrm{~g} ; 0,5 \% \mathrm{CMC}$ (Arifin et al., 2019).

\section{Pengambilan sampel}

Sampel berupa kompos dari limbah pertanian kelapa sawit di ambil dari bagian atas dan bagian tengah dari tumpukan TKKS. Kemudian di ukur pH dan suhunya. Sampel kemudian dimasukkan ke dalam wadah untuk dibawa ke laboratorium.

\section{Isolasi Jamur}

Sebanyak 25 gram sampel kompos TKKS dimasukkan ke dalam Erlenmeyer berisi $225 \mathrm{ml}$ aquades lalu divorteks sehingga diperoleh pengenceran $10^{-1}$. Selanjutnya dilakukan pengenceran berseri hingga didapat pengenceran $10^{-8}$. Media yang digunakan untuk isolasi jamur yaitu media PDA. Dari pengenceran $10^{-1}$ sampai $10^{-8}$ diambil sebanyak $100 i ̀ l$ suspensi kemudian diinokulasi pada media dengan menggunakan metode sebaran (spread plate). Selanjutnya diinkubasi pada suhu ruang selama 5 hari (Cappucino et al., 2014).

\section{Pemurnian Jamur}

Koloni yang berumur 5 hari pada media PDA dipurifikasi menggunakan metode streak ke dalam petri yang sudah berisikan media PDA dan diinkubasi pada suhu ruang selama 5 hari. Pemurnian Jamur dilakukan dengan mengambil koloni yang tumbuh terpisah dan menunjukkan karakter yang berbeda, kemudian ditumbuhkan pada media baru dengan metode di titik di tengah sehingga diperoleh koloni tunggal. Selanjutnya diinkubasi pada suhu ruang selama 5 hari.

\section{Uji Potensi Selulolitik Isolat Jamur}

Pengujian dilakukan dengan menggunakan metode titik ke dalam media CMC plate dan diinkubasi pada suhu ruang selama $48 \mathrm{jam}$. Uji aktivitas selulolitik dilakukan dengan metode Gram's iodine dan dilakukan secara duplo (Kasana et al., 2008). Koloni jamur yang memiliki potensi aktivitas selulolitik diindikasikan dengan terbentuknya zona bening di sekitar koloni setelah diuji dengan Gram's iodin dan dibiarkan selama 3-5 menit. Indeks aktivitas selulase dapat ditentukan dengan cara mengukur rasio diameter zona bening terhadap diameter koloni.

\section{Karakterisasi dan Identifikasi Isolat jamur terpilih}

Isolat terpilih yang memilki indeks selulolitik tinggi selanjutnya dikaraterisasi secara makroskopis dan mikroskopis. Berdasarkan karakter tersebut isolat jamur diidentifikasi. Identifikasi mengacu pada buku panduan identifikasi jamur seperti, Pictrorial Atlas of Soil and Seed Fungi 3rd Edition dan Mycology and Microbiology (Watanabe, 2010; Manoharachary et al., 2016). 


\section{HASIL DAN PEMBAHASAN}

Hasil isolasi jamur dari sampel tandan kosong kelapa sawit terdekomposisi diperoleh sebanyak 18 isolat jamur. Jamur tersebut selanjutnya dilakukan uji potensi selulolitik pada media CMC. Hasil dari pengujian tersebut menunjukkan sebanyak 17 isolat mampu tumbuh pada media tersebut dan 1 isolat tidak mampu tumbuh. Media CMC merupaka media selektif yang hanya bisa ditumbuhi oleh mikroorganisme yang mampu menghidrolisis selulosa. Oleh sebab itu, isolat jamur yang mampu tumbuh pada media ini memiliki kemampuan selulolitik dengan memanfaatkan selulosa di dalam media sebagai satu-satunya sumber karbon (A rifin et al., 2019). Kemampuan selulolitik tersebut dapat berbeda antar isolat jamur. Hal ini dapat dilihat dari indeks selulolitiknya. Semakin tinggi indek selulolitik yang dimiliki oleh isolat jamur, maka semakin tinggi pula potensi selulolitiknya. Tabel 1 menunjukkan indeks selulolitik dari isolat jamur yang diperoleh dari sampel TKKS.

Tabel 1 menunjukkan indek selulolitik paling tinggi dimiliki oleh isolat JM714 yaitu sebesar 6,5. Indeks selulolitik ini menunjukkan bahwa isolat tersebut memiliki kemampuan selulolitik sehingga mampu mendegradasi selulosa yang ada dalam media. Jamur selulolitik diketahui mampu mesekresikan enzim selulase yang dapat memutus ikatan â- 1-4 glikosidik yang menghubungkan monomer D-glukosa dalam molekul selulosa (Nelson and Cox, 2017). Indeks selulolitik yang berbeda menandakan bahwa terdapat perbedaan dari masing-masing isolat dalam menghasilkan enzim selulase untuk menghidrolisis selulosa pada media CMC (Hasanah dan Iwan, 2015).
Kemampuan jamur mendegradasi CMC mendukung pertumbuhan miselia jamur karena bentuk selulosa yang lebih sederhana yang dapat dihidrolisis dengan mudah (Ezekiel et al., 2010).

Berdasarkan Sutari (2020), terdapat 3 kategori potensi selulolitik jamur berdasarkan indeks selulolitik (IS), yaitu jamur dengan potensi selulolitik rendah yang ditandai dengan nilai IS $<1$, jamur dengan potensi selulolitik sedang yang ditandai dengan nilai 1e"ISe"2, serta jamur dengan potensi selulolitik tinggi yaitu jika nilai IS $>2$. Hasil uji selulolitik jamur dari sampel TKKS ini terdapat sebanyak 9 isolat yang termasuk kategori potensi selulolitik rendah yaitu isolat JM505, JM506, JM607, JM611, JM712, JM713, JM715, JM716 dan JM818, sebanyak 5 isolat dengan kategori potensi selulolitik sedang yaitu JM503, JM504, JM608, JM610 dan JM817, serta sebanyak 3 isolat dengan potensi selulolitik tinggi yaitu JM609, JM402 dan JM714 dengan indeks selulolitikmasing-masing sebesar 2,1,3,47 dan 6,5.

Tabel 1.Indek Selulolitik isolat jamur asal TKKS terdekomposisi

\begin{tabular}{ccc}
\hline No & Kode & Indeks Selulolitik (IS) \\
\hline 1 & JM402 & 3,47 \\
2 & JM503 & 2 \\
3 & JM504 & 1,5 \\
4 & JM505 & 0,43 \\
5 & JM506 & 0,34 \\
6 & JM607 & 0,2 \\
7 & JM608 & 1,68 \\
8 & JM609 & 2,1 \\
9 & JM610 & 1 \\
10 & JM611 & 0,24 \\
11 & JM712 & 0,51 \\
12 & JM713 & 0,07 \\
13 & JM714 & 6,5 \\
14 & JM715 & 0,40 \\
15 & JM716 & 0,1 \\
16 & JM817 & 1,82 \\
17 & JM818 & 0,28 \\
\hline
\end{tabular}


Dari 18 isolat yang diperoleh, persentase paling besar adalah kategori indeks selulolitik rendah, yaitu sebesar 50\%, sementara isolat dengan potensi selulolitik tinggi sebesar $17 \%$, dan hanya hanya $5 \%$ atau 1 isolat yang tidak menunjukkan potensi selulolitik (Gambar 1). Isolat ini diduga memanfaatkan sumber karbon selain selulosa pada substrat TKKS.

Isolat yang memiliki potensi selulolitik ditandai dengan terbentuknya zona bening yang ada disekitar koloni jamur. Zona bening ini semakin jelas terlihat setelah media CMC yang ditumbuhi jamur tersebut ditetesi denganlarutan iodin selama 3-5 menit(Gambar2). Bagian zona bening merupakan produk hidrolisis selulosa berupa gula sederhana yang tidak membentuk kompleks ikatan dengan iodin. Sementara warna biru tua atau kehitaman merupakan sisa selulosa yang tidak teruraikan sehingga membentuk kompleks selulosaiodin (Kasana et al., 2008).

Berdasarkan hasil uji potensi selulolitik, tiga isolat jamur yang paling berpotensi untuk mendegradasi selulosa kemudian diidentifikasi. Isolat JM714 yang memiliki potensi selulolitik paling tinggi memiliki koloni dengan karakter miselium aerial berwarna hijau kecokelatan dan miselium vegetatif berwarna kecokelatan (Tabel 2). Secara mikroskopis isolat ini memiliki hifa yang bersekat dan bercabang. Jamur ini

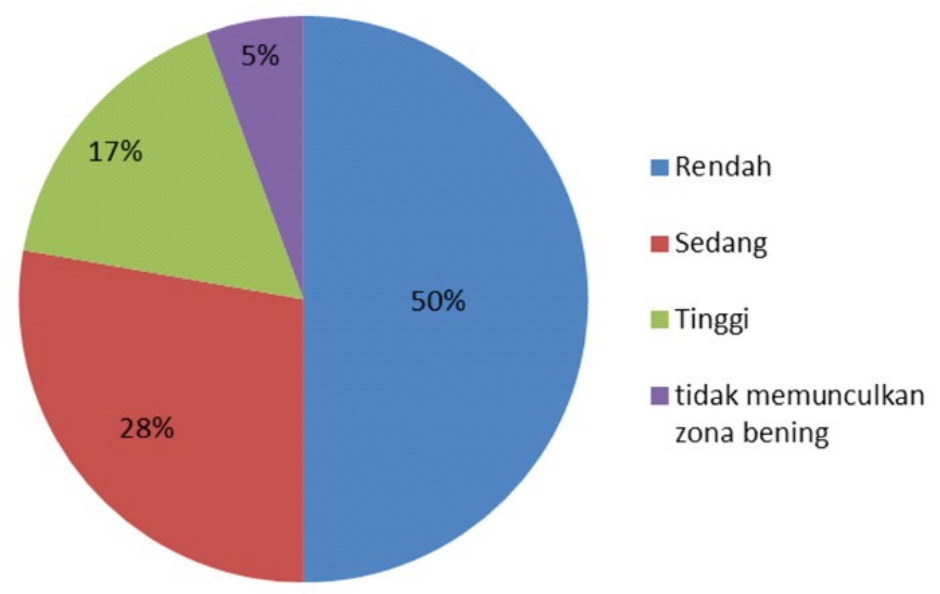

Gambar 1. Persentase jumlah isolat jamur berdasarkan kategori potensi selulolitik
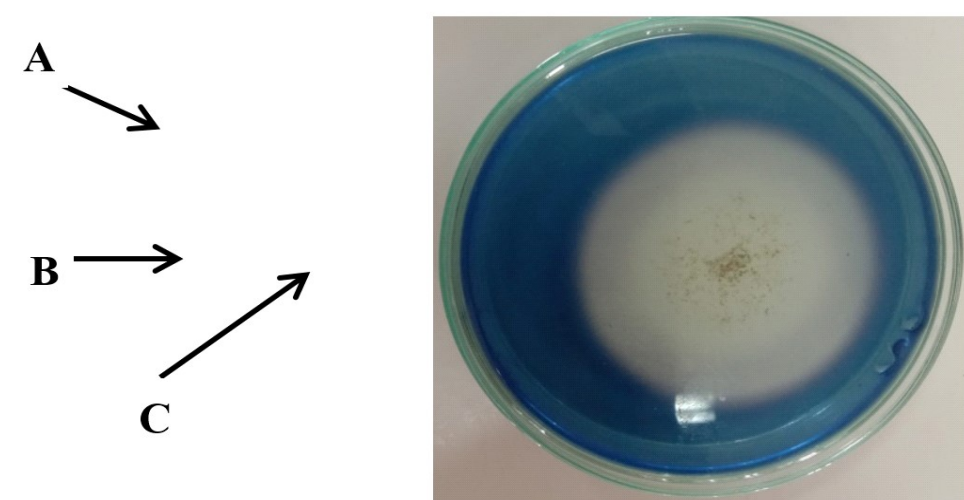

Gambar 2. Hasil uji potensi selulolitik isolat jamur asal TKKS pada media CMC yang telah diteteskan dengan iodin (A. Media CMC B. Zona bening C. Koloni Jamur). 
Tabel 2. Kenampakan makroskopis dan mikroskopis isolat jamur yang memiliki potensi selulolitik

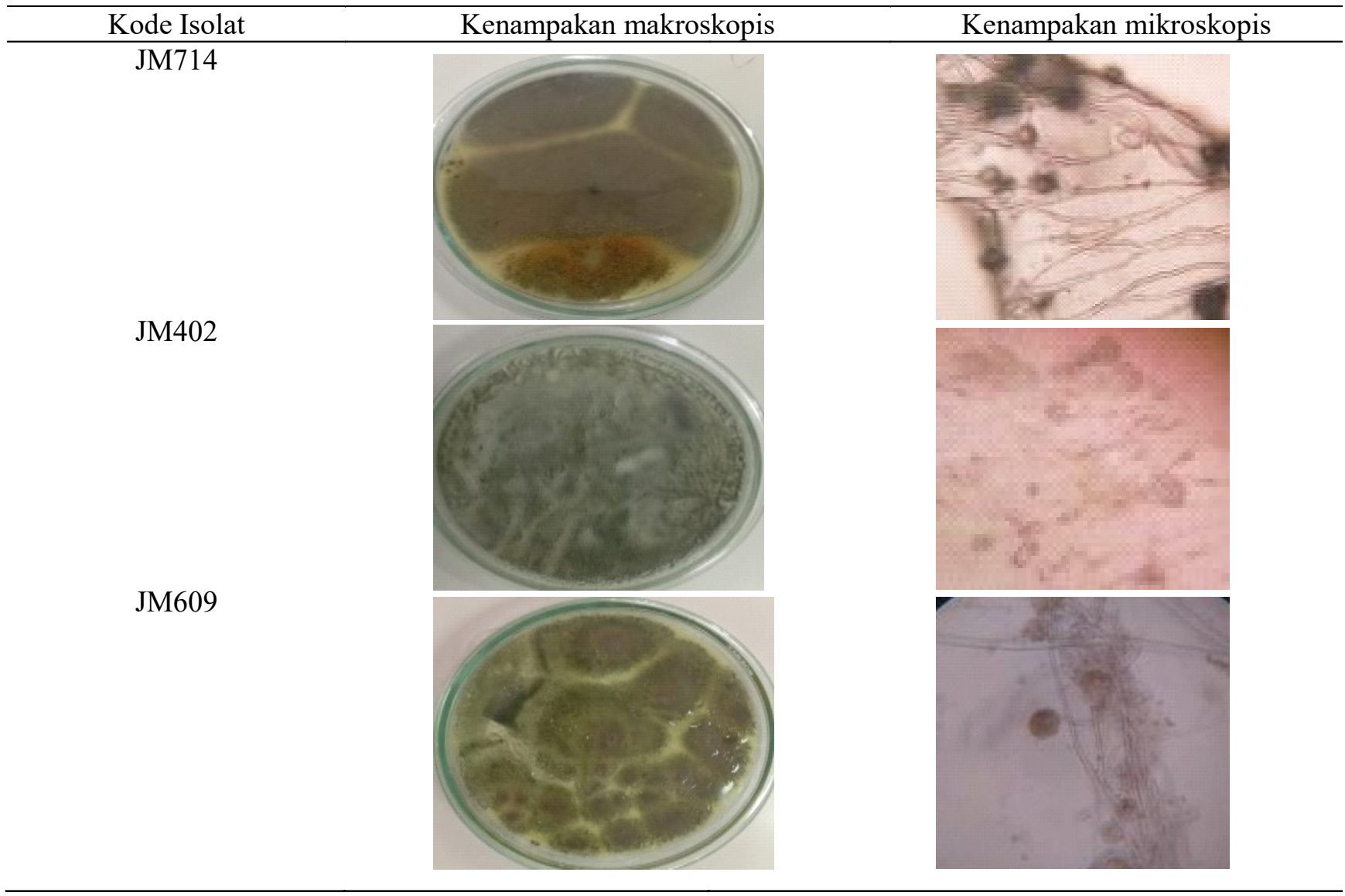

tumbuh membentuk koloni mold yaang berserabut dengan tekstur yang lembut. Jamur ini diduga kuat merupakan anggota dari genus Aspergillus. Penelitian Subowo (2015) menunjukkan bahwa salah satu anggota genus ini yaituAspergillus niger terbukti mampu menguraikan selulosa dengan aktivitas enzim selulase yang dihasilkan sebesar 0,031 unit/mL. Hasil yang sama juga diperoleh dari penelitian Guruchandran dan Sasikumar (2010) yang menggunakan A. niger untuk fermentasi serbuk gergaji dan serasah dengan aktivitas enzim selulase yang dihasilkan mencapai 0,0846 IU/ $\mathrm{mL}$ dan 0,0682 IU/mL. Menurut Subowo (2015) aktivitas enzim selulase yang dihasilkan oleh $A$. Niger dapat bekerja secara optimum pada suhu $50^{\circ} \mathrm{C}$ dengan $\mathrm{pH} 7$, sehingga jamur tersebut dapat digunakan untuk mendegradasi limbah selulosa dari sektor pertanian maupun industri kertas. Selain A. Niger, anggota lain dari genus Aspergillus yaitu Aspergillus fumigatus juga diketahui memiliki peran dalam proses dekomposisi TKKS. Hasil penelitian Kusmardini et al. (2016) menyatakan bahwa $A$. fumigatus dapat mendegradasi komponen lignin yang terkandung pada limbah TKKS secara efektif. Proses lignifikasi ini sangat membantu untuk mencapai proses degradasi lanjutan dari dekomposisi TKKS yaitu penguraian selulosa dan hemiselulosa.

Isolat JM402 secara makroskopis menunjukkan karakter miselium aerial berwarna hijau dengan permukaan koloni yang datar (Tabel 2). Isolat ini memiliki pola pertumbuhan yang khas yang ditunjukkan 
dengan pertumbuhan awal koloni berwarna putih, bagian tengah berwarna hijau muda dan seiring meluasnya koloni warna miselium berubah menjadi hijau tua berbentuk lingkaran. Dengan pola pertumbuhan tersebut, isolat ini diduga merupakan anggota dari genus Trichoderma. Isolat 817 juga menunjukkan pola pertumbuhan yang serupa dengan isolat 402, sehingga isolat ini juga diduga merupakan anggota dari genus Trichoderma. Selain Aspergillus, Trichoderma juga merupakan kelompok jamur selulolitik yang paling banyak ditemukan pada beberapa sampel seperti tanah sawah, limbah rumah tangga dan lahan gambut. Penelitian Reanprayoo and Pathomsiriwong (2012) menunjukkan bahwa genus ini paling banyak ditemukan pada lahan persawahan yang memberikan keuntungan dengan peningkatan jumlah bahan organik sehingga tanah menjadi subur. Selain memiliki enzim selulase, penelitian ini juga membuktikan bahwa kelompok Trichoderma juga memiliki enxim xilanase, peroksidase dan laccase yang mampu membantu proses dekomposisi. Manfaat lainnya dari Aspergilus sp. dan Trichoderma sp. yaitu dapat digunakan untuk pengolahan pakan ternak dari limbah padat bioetanol. Keduanya memiliki daya selulolitik yang cukup tinggi, sehingga dapat meningkatkan kandungan protein, energi, bahan kering dan mampu mendegradasi serat kasar pada limbah padat bioetanol sehingga mutu limbah menjadi lebih baik untuk dikonsumsi ternak (Suryani et al., 2012).

\section{KESIMPULAN}

Berdasarkan hasil isolasi jamur dari sampel TKKS diperoleh total sebanyak 18 isolat, dengan 17 isolat memiliki potensi selulolitik. Isolat JM714, JM402 dan JM609 merupakan isolat jamur yang paling berpotensi dalam mendegradasi selulosa dengan masing-masing indeks selulolitik berturut-turut sebesar $6,5,3,47$ dan 2,1. Setelah dilakukan identifikasi isolat JM714 diduga merupakan anggota genus Aspergillus, sementara isolat JM402 dan JM609 adalah anggota genus Trichoderma.

\section{UCAPAN TERIMA KASIH}

Penulis mengucapkan terima kasih kepada Direktorat Riset dan Pengabdian Masyarakat (DRPM), Ditjen Penguatan Riset dan Pengembangan Kementerian Riset, Teknologi dan Pendidikan Tinggi yang telahmembiayai penelitian ini. Ucapan terima kasih juga kepada saudara Ovi Olivia dan Rahmat Hidayatdi yang telah banyak membantu dalam pelaksanaan penelitian ini.

\section{DAFTAR PUSTAKA}

Affandi, M. 2001. Diversitas dan visualisasi karakter jamur yang berasosiasi dengan proses degradasi serasah di lingkungan mangrove. Universitas Airlangga.

Aini, D.N., Hanifa, D.S. Mulfa dan T.M. Linda. 2021. Pengaruh Bioaktivator Selulolitik untuk Mempercepat Pengomposan Tandan Kosong Kelapa Sawit (Elaeis guineensis Jacq.). Biota. 6(1):1-7.

Anindyawati, T. 2010. Potensi Selulase dalam Mendegradasi Lignoselulosa Limbah Pertanian untuk Pupuk Organik. Berita Selulosa. 45(2): 70-77. 
Arifin, Z., I.B.W. Gunam, N.S. Antara dan Y. Setio. 2019. Isolasi Bakteri Selulolitik Pendegradasi Selulosa dari Kompos. Jurnal Rekayasa dan Manajemen Agroindustri. 7(1): 30-37.

Cappucino, J.G. and N.Sherman. 2014. Microbiology: A Laboratory Manual, 10th Edition. Pearson. New York.

Ezekiel, C. N., Odebode, A. C., Omenka, R. O., and Adesioye, F. A. 2010. Growth response and comparative cellulase induction in soil fungi grown on different cellulose media. Acta Atech, 3(2), 52-59.

Guruchandran, V and C. Sasikumar. 2010. Cellulase production by Aspergillus niger fermentedd in saw dust and bagasse. J. Cell Tissue Research 10: $2115-2117$.

Hasanah, N., dan Iwan, S. 2015. Aktivitas selulase isolat jamur isolat jamur dari limbah media tanam jamur merang. Pros Sem Nas Masy Biodiv Indon, 1(5), 1110-1115.

Jumirah, Jati, A. W. N., dan Yulianti, L. I. M. 2018. Kualitas Pupuk Cair Organik dengan Kombinasi Limbah Ampas Jamu dan Limbah Ikan. Biota, 3(2), 53-61.

Kadarmoidheen, M., P. Saranraj and D. Stella. 2012. Effect of Cellulolytic Fungi on the Degradation ofCellulosic Agricultural Waste. International Journal of Applied Microbiology Science. 1(2): 13-23.

Kasana, Salwan, Dhar, Dutt and Gulati. 2008. A Rapid dan EasyMethod for the Detection of Microbial Cellulases on Agar Plates Using Gram's Iodine. Curr Microbioll. 57 (2008): 503-507.
Kusmardini, D., J. Prasetyo, S. Hudiyono, E. Saepudin and Adiarso. 2016. The Effectiveness of BioDelignification Empty Fruit Bunh of Palm Oil by Aspergillus fumigatus: Targetting for BioHydrogen Production. International Journal of Applied Chemistry. 12 (3): 411-427.

Manoharachary, C., K.V.B.R. Tilak, K.V. Malaiah and I.K. Kunwar. 2016. Mycology and Microbiology: A Textbook for UG and PG Courses. Scientific Publishers. New Delhi. India.

Murdani, F. C. 2017. Pengolahan Tandan Kosong Kelapa Sawit (TKKS) Sebagai Alternatif Material Tekstil. e-Proceeding of Art \& Design, 4(3), 1187-1206.

Nelson, D.L. and M.M.Cox. 2017. Lehninger Principles of Biochemistry 7th Edition. Madison. New York.

Rahman, M. A. A., Nour El-Din, M., Refaat, B. M., Abdel-Shakour,E.H.,Ewais, E.E.D., \&Alrefaey, H. M. A. 2016. Biotechnological Application of Thermotolerant Cellulose-Decomposing Bacteria in Composting of Rice Straw. Annals of Agricultural Sciences, 135-143.

Reanprayoon, P., and Wattanachai, P. 2012. Tropical soil fungi producing cellulase and related enzymes in biodegradation. Jurnal of Applied Sciences, 12(18): 1909-1916.

Saha, B.C. 2004. Lignocellulose Biodegradation and Application in Biotechnology. US Government Work. American Chemical Society. 2-14. 
Santi, L.P., D.N. Kalbuadi, and D. H. Goenadi. 2018. Empty Fruit Bunches As A Potential Source For Biosilica Fertilizer For Oil Palm. Prosiding Seminar Nasional Biologi Tropika pada 28 Juli 2018. Universitas Gadjah Mada.Yogyakarta.

Subowo, Y.B. 2015. Isolasi dan Seleksi Jamur Tanah Pengurai Selulosa dari Berbagai Lingkungan. Pros Sem Nas Masy Biodiv Indon. 1(3):423-427.

Suryani, Y., Andayaningsih, P. dan Hernaman, I. 2012. Isolasi dan identifikasi jamur selulolitik pada limbah produksi bioetanol dari singkong yang berpotensi dalam pengolahan limbah menjadi pakan domba. Jurnal Istek, 6(2), 1-10.

Sutari, N.W.S. 2020. Isolasi dan Identifikasi Morfologi Jamur Selulolitik dari Limbah Rumah Tangga di Desa Sanur Kauh, Bali. Agrovigor: Jurnal Agroekoteknologi. 13(2): 100-105.

Watanabe, T. 2010. Pictorial atlas of soil and seed fungi morphologies of cultured fungi and key of species 3nd. Taylor \& Francis Group. 